\title{
Kirjasto osallisuuden ja yhteistyösuhteiden solmukohtana
}

\author{
Ritva Hyttinen \\ Turun ammattikorkeakoulu \\ ritva.hyttinen@turkuamk.fi \\ https://orcid.org/0000-0002-3818-4971 \\ Ilona Tanskanen \\ Turun ammattikorkeakoulu \\ ilona.tanskanen@turkuamk.fi \\ https://orcid.org/0000-0002-6865-5834
}

Asiasanat: kirjastot; vuorovaikutus; nuoret aikuiset; syrjäytyminen; taidelähtöiset menetelmät; osallisuus

Vuoden 2017 alussa voimaan astunut yleisiä kirjastoja koskeva lainsäädäntö (FINLEX 1492/2016, ei pvm.) näyttäisi laajentavan kirjaston yhteiskunnallista toimintasädettä ja kasvattavan sen yhteisöllistä vastuuta. Lakiin on kirjattu, että yleisen kirjaston tehtävä on muun muassa tukea monimuotoista yhteiskuntaa, demokratiakehitystä sekä yksilöiden ja yhteisöjen osallisuutta. Kirjastoilta odotetaan entistä parempaa yhteisön tarpeiden tuntemusta ja kykyä tavoittaa myös ne, jotka eivät koe kirjastopalveluita omikseen. Yhden haastavan kohderyhmän muodostavat yhteiskunnan marginaaliin ajautumassa olevat nuoret aikuiset, joita kirjasto ei juuri tunne. Mistä nämä nuoret aikuiset voisi löytää ja miten käynnistää vuoropuhelu heidän kanssaan? Näkymättömät - Nuorten digitarinat -hankkeessa on luotu toimintamalli, joka auttaa juuri näissä kysymyksissä. Toimintamallin tärkeä osa ovat taide- ja medialähtöiset työpajat, jotka toimivat vuorovaikutteisina kohtaamispaikkoina nuorille, kirjastoille sekä eri nuorisotoimijoiden sektoreille. Toimintamallin tavoite on kannustaa yhteiskunnan toimijoita voimaannuttamaan erityisesti niitä nuoria aikuisia, joiden mahdollisuudet toimia yhteisöissä ovat kaventuneet lähes olemattomiin.

Artikkeli on lisensoitu Creative Commons Nimeä-EiKaupallinen-JaaSamoin 4.o Kansainvälinen -lisenssillä

Pysyvä osoite: https://doi.org/10.23978/inf.71159 
Tässä artikkelissa tarkastellaan kysymystä, miten luoda ja ylläpitää vuorovaikutussuhteita niin eri organisaatioiden välillä kuin nuorille järjestettävässä työpajatoiminnassakin. Ensin luomme katsauksen kirjastojen tehtävään ja nuorten syrjäytymiseen yhteiskunnassa. Sitten tarkastelemme Näkymättömät - Nuorten digitarinat -hankkeen työpajatoimintaa ja siinä esiin nousseita huomioita nuorten osallisuuden tukemisesta taide- ja medialähtöisiä menetelmiä soveltavassa toiminnassa. Nostamme esiin kysymyksen siitä, millaista on osallisuutta tukeva diskurssi, ja tuomme esiin muutamia siihen liittyviä havaintoja. Lopuksi esittelemme kirjastojen ja yhteistyökumppaneiden käyttöön tarkoitetun Topitkäsikirjan, jossa on tarjolla valikoima konkreettisia ehdotuksia kirjaston ja sen yhteistyökumppaneiden järjestämään nuorten toimintaan.

\section{Kirjasto yhteisössä - yhteisö kirjastossa}

Kirjastolain (FINLEX 1492/2016, ei pvm.) valmisteluasiakirjoissa (FINLEX, 2016) yleinen kirjasto nähdään aktiivisen kansalaisyhteiskunnan voimavarana ja mahdollistajana. Kirjaston tehtävänä on tarjota yksilöille ja yhteisölle paitsi pääsy tietoon ja kulttuurisisältöihin myös tila ja paikka, jonne kaikki pääsevät ja ovat tervetulleita. Kansalaisyhteiskunta on käsitteenä rikas ja monipuolinen, se on olennainen osa demokraattista järjestelmää. Kansalaisyhteiskunta viittaa niihin rakenteisiin ja toimintoihin, jotka ovat ihmisen yksityiselämän alueella, poissa julkisen vallan tai taloudellisen voiton tavoittelun muodollisilta sektoreilta. Kansalaisyhteiskuntatoimintaan liittyy vapaaehtoisuus, sosiaalisuus ja mukanaolo, joka vastaa yksilön omia intressejä. Kansalaistoiminta voi kiinnittyä esimerkiksi järjestöihin, yhdistyksiin, kerhoihin, vapaaseen sivistystyöhön tai pienimuotoiseen osuustoimintaan. (Harju, 2018.) Aaro Harjun (2003, ss. 10-12) mukaan konkreettinen toiminta ja aktiivinen kansalaisuus ovat kansalaistoiminnan tunnusmerkkejä. Kansalaistoiminta ei tuota yksilölle taloudellista hyötyä vaan mielihyvää, joka tulee yhdessä tekemisestä ja yhteisön parhaaksi toimimisesta. Yleinen kirjasto on tärkeä, mutta toistaiseksi melko näkymätön kansalaisyhteiskunnan tukija. Olisiko kirjaston mahdollista ottaa aktiivisempi rooli? Allianssi ry:n julkaisema selvitys Nuorista Suomessa (2016, s. 7) nostaa esiin, että nuoret olisivat halukkaita vapaaehtoistyöhön, mutta he eivät tunne kenttää eivätkä tiedä, miten toimijoita tavoittaisi. Vapaan toiminnan kenttään kuuluvaksi voidaan lukea monimuotoiset käytäntöyhteisöt, jotka voivat olla yhtä lailla järjestäytynyttä pitkäkestoista toimintaa kuin pientä paikallista puuhastelua. Voisiko kirjasto näyttäytyä käytäntöyhteisön toiminta-alustana?

Etienne Wengerin ja Jean Lavenin (1991) hahmottama malli käytäntöyhtei- 
söistä, communities of practice, on nähty kirjastoalalla sekä kiinnostavana teoriana että käytäntöön sovitettavana toimintamallina. Kirjastoalalla käytäntöyhteisöajattelua on sovellettu monesta eri tulokulmasta, ja sitä on kiinnitetty osaksi informaatiolukutaitoa, kirjastoalan koulutusta, käytännön kirjastotyötä sekä laajemmin tieteellisen ja yleisen kirjaston toimintaan (ks. Burns, Howard, \& Kimmel, 2016; Joy \& Vijayakumar, 2016; Kim, 2015; Lloyd, 2005). Wengerin (1998) mukaan käytäntöyhteisöjä on kaikkialla ja ne voivat liittyä yhtä lailla kotiympäristöön kuin työelämään tai harrastuksiin. Käytäntöyhteisöt voivat olla muodollisia kokoonpanoja, jotka tähtäävät tiettyihin tavoitteisiin, asioihin tai toimintoihin, mutta ne voivat myös olla vapaamuotoisempaa puuhastelua. Kaikkiin törmäämiinsä yhteisöihin yksilö ei kiinnity, joihinkin hän ei tunne lainkaan vetoa, toisissa yhteisöissä hän vain pistäytyy, joihinkin hän jää pidemmäksi aikaa, kun taas johonkin yhteisöön hän voi sitoutua koko elämäkseen. Pitkäikäisissä ja lujissa yhteisöissä toimijoita yleensä liittää yhteen jaettu ymmärrys tavoitteista, toiminnasta ja toimintatavoista. Parhaimmillaan ihmisellä on valtuus ja vapaus toimia yhteisönsä tunnustettuna jäsenenä, kun yhteisö puolestaan tukee hänen kasvuaan ja antaa hänelle tilaa muotoutua omaksi itsekseen. Identiteetin kannalta jäsenyys ja osallisuus ovat tärkeitä. Kriittisiksi pisteiksi ne muodostuvat päinvastaisissa tilanteissa eli silloin, kun ihminen on vaarassa ajautua tai jäädä kaikkien yhteisöjen tai verkostojen ulkopuolella. Tämä voi olla tilanne, kun yksilö ei löydä yhteisöä, joka vastaisi hänen intressejään, tai kun hän ei syystä tai toisesta pääse mukaan ryhmän toimintaan. Erityisen haastava tilanne on silloin, kun ihminen on jumittunut marginaaliin ja hänen liikkumamahdollisuutensa suuntaan tai toiseen ovat mitättömät. Reunalta hän ei pääse siirtymään yhteisön sisäpiiriin, eikä hän omin avuin löydä uutta kollektiivia, joka vastaisi hänen tarpeitaan. (Wenger, 1998, ss. 164-168.) Tilanteessa, jossa yksilö jää yksin ja on vaarassa ajautua yhteisöjen tavoittamattomiin, hän tarvitsee ulkopuolista tukea löytääkseen uuden sosiaalisen verkoston. Osallistava ja yhteisöä tukeva kansalaisyhteiskunnan kirjasto voisi olla luonteva paikka ja väylä auttaa yksilöä löytämään itselleen sopiva ympäristö, jossa hän voi ilmaista itseään ja saa äänensä kuuluviin.

Kirjastoalalla yhteisöllisyys on ollut olennainen elementti, kun ympäröivien asiakasryhmien tiedontarpeen tunnistaminen on ollut lähtökohtana kirjastopalveluiden muotoilussa ja kehittämisessä (ks. Järvelin, 1989). Tilanne on kuitenkin muuttunut sitä mukaa, kun kuluvan vuosituhannen aikana yhteisöllisyydestä on kasvanut yksi kirjastoalan ammattilaisten keskeisimmistä osaamisalueista. Näin ollen yhteisöllisyydellä kirjastoalalla ei viitata asiakkaiden, käyttäjien tai ei-käyttäjien reserviin, johon kirjastoammattilainen tukeutuu tilanteen niin vaatiessa. Satunnaisten kohtaamisten sijaan tavoitellaan jatkuvaa dialogia ja konkreettista yhteistyöstä eri suuntiin yhteiskunnassa. Tätä kautta kirjastolla on 
mahdollisuus saada suora yhteys eri yhteisöihin; se kuulisi yhtä lailla reunoilta kuin keskustastakin tulevia signaaleja ja kykenisi reagoimaan niihin. Toisaalta yhteisöt odottavat kirjastoilta ketteryyttä, aloitteellisuutta ja aktiivisuutta, mutta myös sitä, että kirjasto itse sanoittaa oman roolinsa. Kaiken kaikkiaan yhteisöllisyys on kirjastoalalla paitsi keskeinen kompetenssi myös tärkeä elementti alan eettisessä koodistossa. Kirjastoalan ammattilaisen tulisi toimia ennakkoluulottomasti ympäröivissä yhteisöissä, yhtälailla asiakkaiden keskuudessa kuin eri ammattikuntien ja toimijoiden verkostoissa. (Gutsche \& Hough, 2014.)

\section{Näkymättömät nuoret aikuiset}

Syrjäytyminen on suuri yhteiskunnallinen ongelma Suomessa. Nuorisojärjestö Allianssin (2016, s. 41) mukaan vuonna 2010 Suomessa oli 51.300 syrjäytynyttä 15-29-vuotiasta nuorta aikuista, ja 24.10.2017 Helsingin Sanomat uutisoi luvun olevan 70.00o. Luvut ovat hälyttäviä, ja vielä huolestuttavammaksi tilanteen tekee se, että Suomessa nuorten ajautuminen yhteiskunnan ulkopuolelle on paljon yleisempää kuin muissa Pohjoismaissa (Eurostat, 2016). YK:n julkaiseman raportin Leaving no one Behind (UN, 2016, ss. 17-19) mukaan syrjäytyminen viittaa tilanteeseen, jossa yksilö ei osallistu millään tavoin yhteiskunnan toimintaan. Reunalle ajautunut ihminen on poissa yhteisiltä areenoilta, häntä ei näy poliittisissa, taloudellisissa, kulttuurisissa tai sosiaalisissa kerrostumissa. Ulkopuolisuus vaikuttaa voimakkaasti identiteettiin, eikä ainoastaan yksilötasolla vaan myös ryhmätasolla, ja leimaa ihmiset yhteiskunnan marginaaliin. Marginaalissa elävät eivät ole omalla äänellään mukana yhteiskunnan keskustelussa, vaan monesti he jäävät ja heidät jätetään syrjään myös niistä tilanteista, joissa käsitellään heihin liittyviä asioita. (UN, 2016.) Jo syrjäytymisriskiin ajautuneen nuoren elinpiiri on kaventunut, eikä hänellä ole kanavia, joiden kautta hän voisi vaikuttaa - ja toisaalta valmiudet vaikuttaa voivat olla vaatimattomat. Vaikka kukaan ei ole täysin turvassa syrjäytymiseltä, ilmiö liittyy usein vähäosaisuuteen, vähemmistötaustaan sekä matalaan koulutustasoon, joka periytyy helposti seuraavalle sukupolvelle. Suomalainen peruskoulu ei kykene kuromaan kiinni kotitaustan eroja, vaan korkeasti ja matalasti koulutettujen vanhempien lasten ero koulumenestyksessä on selvä, ja peräti $15 \%$ ikäluokasta jää pelkän peruskoulun varaan. Tärkeää olisi, että nuori pääsisi jatkamaan opintojaan peruskoulun jälkeen. Mikäli opinnot eivät jatku tai hän ei kykene viemään loppuun toisen asteen opintoja, riski ajautua huono-osaisuuden kierteeseen kasvaa merkittävästi. (Oma Linja, 2016.)

Turun kaupunginteatterin 2017 esittämä tulkinta Aleksis Kiven Seitsemästä veljeksestä kuvaa railakkaasti yhteisöä ja sen merkitystä oppimiselle. Veljesten 
vahvuus on se, että heillä on toisensa, ja yhdessä he puskevat toisiaan eteenpäin opintiellä. Nuorille kaverisuhteet ovat tärkeitä, ja ne menevät perheen, koulutuksen ja työn edelle, kun taas yksinäisyys koetaan häpeäksi, josta ei haluta puhua. Nuoren yksinäisyys on musertava ongelma, joka saa hänet kokemaan ulkopuolisuutta, näkymättömyyttä ja kelpaamattomuutta. (Allianssi, 2016, ss. 2224; Junttila, 2015, S. 13.) Lukukeskuksen vuonna 2017 julkaiseman 10 faktaa lukemisesta -tietopaketin mukaan lukutaito lisää sosiaalista identiteettiä, kun taas lukutaidoton jää helposti yksin. Suomalaisista $11 \%$ on heikkoja lukijoita, eli käytännössä tämä tarkoittaa, että joka kymmenennelle opintojen jatkaminen ja työelämään pääsy voi olla haastavaa huonon lukutaidon takia. (Lukukeskus, 2017.) Heikko lukutaito on kysymys, jonka edessä nuori aikuinen voi kokea voimattomuutta, sillä yhteiskunnasta näyttäisi puuttuvan selkeä taho, joka auttaa silloin, kun on tarve parantaa lukutaitoa. Hyviä lukijoita ja kirjoittajia tuetaan esimerkiksi kirjoittajakouluissa ja lukupiireissä, mutta ihminen joka haluaa peruskoulun jälkeen kohentaa vaatimatonta luku- ja kirjoitustaitoaan, on hankalassa tilanteessa.

Näkymättömät - Nuorten digitarinat -hankkeen kokemusten mukaan heikko lukutaito ja kirjasto näyttäisivät olevan toisensa poissulkeva yhtälö. Nuoret aikuiset, joiden lukutaito on jäänyt heikoksi, eivät koe kirjastopalveluita omakseen. Lisäksi he ovat kirjastopalveluissa ilman selkeää osoitetta, sillä nuorille suunnatut palvelut eivät enää vastaa heidän tarpeitaan eivätkä he koe kuuluvansa aikuisten ryhmään. Näkymättömät-hankkeessa Turun ja Seinäjoen ammattikorkeakoulut sekä Jyväskylän yliopisto ovat soveltaneet media- ja taidelähtöisiä työpajoja yhteisön ulkokehälle ajautuneiden nuorten aikuisten osallistamiseen ja kuuntelemiseen sekä tarjonnut nuorille areenan tulla kuulluksi. Lisäksi kolmevuotisen (2015-2018) ESR-rahoitteisen hankkeen tavoitteena on ollut löytää käytäntö tukemaan yleisten kirjastojen roolia nuorten osallisuutta tukevana ja rohkaisevana paikkana. Hankkeessa on kehitetty Topit-toimintamalli, joka on julkaistu verkkokäsikirjana ${ }^{1}$. Topit painottaa erityisesti yhteiskunnan eri toimijoiden yhteistyötä, jossa otetaan huomioon kunkin voimavarat ja vahvuudet. Etsivä nuorisotyö, nivelvaiheen koulutukset sekä kolmannen sektorin järjestöt ja yhdistykset ovat ketteriä toimijoita ja luontevia väyliä tavoittaa nuoria aikuisia. Nämä eivät ole välttämättä nähneet yleistä kirjastoa aktiivisena toimijana osallistamisen kentällä. Kysymys onkin ehkä siitä, että kirjastot ovat vasta viime vuosina havahtuneet sanoittamaan uutta rooliaan kansalaisyhteiskunnassa. Esimerkiksi Helsingin kaupungin kirjaston hanke Kirjasto treenaa nuoria (2016) on pyrkinyt konkretisoimaan kirjaston tehtävän nuorisotakuun toteuttamisessa. 


\section{Näkymättömät - Nuorten digitarinat}

Näkymättömät - Nuorten digitarinat -hanke järjesti Jyväskylässä, Seinäjoella ja Turussa taide- ja medialähtöisiä menetelmiä soveltavia työpajoja koulutuksen ja työelämän ulkopuolella oleville nuorille. Työpajatoiminnan tavoitteena oli nuorten näkyville tulo ja kuulemien: omien tarinoiden kertominen ja julkistaminen, mikäli nuori haluaisi. Työpajoissa nuoret kertoivat kokemuksistaan ja unelmistaan esimerkiksi digitarinoiden muodossa. Näin he tulivat nähdyiksi ja kuulluiksi ainakin omassa ryhmässään, mutta monet myös julkaisivat tarinansa Näkymättömät-hankkeen YouTube-kanavalla (ks. ”Näkymättömät - Nuorten digitarinat 2018", ei pvm.). Hankkeen työpajoissa tavoitteena oli tukea nuorten osallisuutta taide- ja medialähtöisiä menetelmiä soveltaen.

Näkymättömät-hankkeen työpajatoiminnan ja työpajaohjaajien valmentamisen ytimessä oli ihmisenä elämisen peruskysymys: miten tulla toimeen ja kommunikoida toisten ihmisten kanssa. Se voi tuntua äkkiseltään itsestään selvältä asialta mutta on kaikkea muuta kuin sitä.

Joskus syrjäyttävät tai osallistavat käytänteet ovat sellaisia tapoja toimia, joita pidetään yhteisöissä tavallisina. Syrjäyttämisessä tai osattomuuden synnyttämisessä ei siis välttämättä ole kysymys erityisen vieroksuvasta toiminnasta. Voi olla yksinkertaisesti niin, että tietyissä yhteisöissä luonnolliset toimintatavat saattavat syrjäyttää sellaisia ihmisiä tai ihmisryhmiä, joille toimintatapa on vieras tai mahdoton. Osittain tähän perustuu esimerkiksi maahanmuuttajien riski syrjäytyä, mikäli heillä ei ole valtaväestön kielen ja kulttuurin tuntemusta ja osaamista. Silloin kun toimitaan jo syrjäytyneiden tai syrjäytymisvaarassa olevien ihmisten kanssa, on tarpeen kiinnittää erityistä huomiota vuorovaikutustapoihin. Voi olla, että itselle luonnolliset kommunikointitavat ovat sellaisia, että niissä ei oteta huomioon tällaisia ihmisiä. (Dijk, 2008, ss. 29-31, 63-66; Heikkinen, 1999, s. 90; Karvonen, 1995, ss. 30-32, 71-79.)

Yksilön näkökulmasta osallisuutta on tunne kuulumisesta joukkoon, meihin. Osallisuuteen sisältyy myös mahdollisuus tehdä valintoja. Syrjäytymistä voi pitää osallisuuden vastakohtana: tunteena, ettei kuulu (ainakaan tähän) joukkoon ja ettei ole mahdollisuutta vaikuttaa asioihin valintoja tekemällä, koska valinnan mahdollisuuksia ei ole tai niitä ei näe. Kysymys on yksilöiden tulkinnoista, mutta ei yksin niistä. Tulkinnat perustuvat kokemuksiin siitä, miten on tullut nähdyksi, kuulluksi ja kohdelluksi. Usein syrjäytymiseen liitetään passiivisuus, se ettei yksilö toimi osana yhteisöä. Kokemus ulkopuolisuudesta ja siitä, että on osaton resursseista, joita yhdessä toimimisessa tarvitaan, voi johtaa siihen, ettei halua tai kykene toimimaan yhteisössä. (Ks. Salonen, 2017; THL, 2017.)

Voimauttavassa ja osallisuutta tukevassa toiminnassa on tarpeen kyky tunnistaa erilaisia sosiaalisia ja vuorovaikutukseen liittyviä käytänteitä vaikutuksi- 
neen ja tarvittaessa toimia toisin kuin tavallisesti. Tarvitaan kriittistä kielitietoisuutta ja diskurssianalyysiä - sen tiedostamista, millaisia tulkintoja, merkityksen muodostamisen mahdollisuuksia ja vaikutuksia eri ihmisille erilaisilla toiminnan ja kommunikoinnin tavoilla on ja voi olla (Fairclough, 2010, ss. 30, 3941, 63; Janks \& Ivanič, 1992, ss. 305-330).

Turussa Näkymättömät - Nuorten digitarinat -hankkeessa nuorille (15-29vuotiaille) osallistujille järjestetyissä työpajoissa ohjaajina toimivat Turun ammattikorkeakoulun kirjasto- ja taidealan opiskelijat. Työpajaohjaajien valmennuksessa ja työpajoissa huomio kiinnittyi siihen, miten vaativaa vuorovaikutussuhteen luominen ja ylläpitäminen entuudestaan tuntemattoman ihmisen kanssa on. On tarpeen tarkastella kommunikoinnin käytänteitä ja sitä, miten muodostaa nimenomaan osallisuutta tukevia vuorovaikutuksen muotoja. Miten luoda turvallinen ja miellyttävä, kommunikoinnin ja yhdessä toimimisen tila jossa näyttäytyminen ja kuunteleminen ovat mahdollisia?

Työpajaohjaajia valmennettaessa kävi ilmi, että kovin helposti toistamme vuorovaikutussuhteissamme niitä tapoja, joita olemme vastaavanlaisissa tilanteissa, esimerkiksi juuri eri oppilaitoksissa, itse kokeneet. Tämän vuoksi jo työpajaohjaajien valmennuksessa ja etenkin työpajoissa tulisi pyrkiä yhdessä tutkimiseen ja tekemiseen, jolloin osallistujalla on aktiivinen rooli ja ohjaaja toimii pikemminkin tuutorina tai valmentajana. Tällainen toimintatapa purkaa perinteistä frontaaliopetusta ja siihen liittyvää epäsymmetristä valtasuhdetta (ks. Turun ammattikorkeakoulu, 2018).

Osallisuutta tukevassa toiminnassa työpajaohjaajan rooli sisältää mahdollistamisen ja innostamisen tehtävät. Sosiokulttuuriseen innostamiseen sisältyy demokraattisuus, moraaliset ja psykologiset painotukset: esimerkiksi rehellisyys, toisten ihmisten kunnioittaminen, avoimuus, sitkeys ja epäitsekkyys (Kurki, 2000, s. 66). Dosentti Leena Kurki toteaa (2000, s. 66): "Innostaja sekä auttaa ihmisiä saavuttamaan ontologisen vapautensa että samalla kristalloimaan uutta kuvaa sosiaalisesta todellisuudesta." Innostaja johtaa johtamatta.

\section{Yhteisöllisyyden rakentaminen vuorovaikutuksessa}

Osallisuuden kokemuksen edellyttämä yhteisöllisyys, kokemus siitä, että itse on osa yhteisöä, rakentuu hiljalleen, sana ja teko kerrallaan. Yksi yhteisöllisyyden muodostamisen keinoista on yhdessä tekeminen - sellaisten asioiden yhdessä tekeminen, jotka kiinnostavat kaikkia osapuolia aidosti. Toimintaa on tarpeen suunnitella ja toiminnan edetessä muokata yhdessä, jotta osallistujat voivat vaikuttaa ja tehdä mielekkäitä valintoja alusta alkaen. Osallistujat eivät välttämättä heti työskentelyn alussa tiedosta sitä, millainen toiminta kiinnostaisi. Siksi toi- 
minnan edetessä on kyettävä reagoimaan esiin nouseviin mielenkiinnon kohteisiin ja otettava ne huomioon. (ks. Parkkinen \& Linnossuo, 2013, s. 21.)

Vuorovaikutussuhde muodostuu kommunikoimalla. Näkymättömättyöpajoissa lähdettiin liikkeelle tutustumisharjoitteilla, esimerkiksi sellaisella, että jokainen kertoi itselleen merkityksellisestä kuvasta samalla kun esittäytyi uudessa ryhmässä. Vieraille ihmisille esittäytyminen on jännittävää, ja mielessä pyörii, mitä ihmettä sanoisin. Kun mukana on jokin esine tai kuva, josta voi kertoa, kuvan tai esineen herättämät mielikuvat tarjoavat sytykkeitä tarinalle, itsestä kertomiselle. Kuvista ja esineistä kertoessaan tulee kertoneeksi itsestään aika paljon muutakin, esimerkiksi juuri kiinnostuksenkohteistaan. (Ks. lisää taidelähtöisistä harjoitteista Parkkinen \& Linnossuo, 2013, ss. 23-93.)

Taide- ja medialähtöiset menetelmät tarjoavat monipuolisen valikoiman työskentelytapoja, joita yhdistää kerronta jossakin muodossa. Varsinkin yhdisteltäessä esimerkiksi sanallisen ja kuvallisen ilmaisun keinoja jokaiselle löytyy omia luontumuksia palveleva ote. Omalla kerronnalla näkyville suostuminen uudessa ryhmässä ei ole kaikille helppoa; tarvitaan turvallinen ryhmä ja rohkaisua. Näkymättömät-työpajatoiminnassa omaa tarinaa tuotettiin vähitellen, yksittäisillä harjoitteilla, joilla rakennettiin valmiuksia tarinan kerrontaan ja omaa digitarinaa.

\section{Aktiivinen kuunteleminen ja vastavuoroinen kommunikointi}

Omaelämäkerralliseen työskentelyyn taide- ja medialähtöisin menetelmin sisältyvät myös ohjaajan tarinat. Jotta kohtaaminen ihmisten välillä olisi mahdollista, etenkin ohjaajan on kyettävä sekä kuuntelemaan että kertomaan omia tarinoitaan. Koko elämäntarinaa ei tarvitse, ole suotavaa eikä edes mahdollista kertoa pitkässäkään työpajassa - vaikka kysymys olisikin omaelämäkerrallisesta työskentelystä, kuten Näkymättömät - Nuorten digitarinat -työpajoissa on ollut. Jotta kohtaaminen olisi mahdollista, tarvitaan yhteisten kiinnostuksen kohteiden lisäksi vastavuoroisuutta, aitoa dialogia (Anttila, Pohjola, \& Löytönen, 2017; Sinisalo-Juha, 2013, ss. 13-14).

Dialogi edellyttää kertomisen lisäksi kykyä kuunnella aktiivisesti ja viestiä toiselle, että todella keskittyneesti kuuntelee ja on kiinnostunut siitä, mitä toinen kertoo. Katsekontakti, nyökyttely ja täsmentävät kysymykset ovat viestejä kuuntelemisesta. Erityisen tärkeää luonteva kuuntelemisen osoittaminen on silloin, kun vuorovaikutuskumppanina on ihminen, joka ei ole tottunut siihen, että juuri häntä kuunnellaan ja hänelle tarjotaan oma tila kertoa. (ks. Välikoski, 2016.) 
Aktiivinen kuunteleminen edellyttää sitä, että pyrkii havainnoimaan kaikilla aisteillaan ja eläytymään toisen tilanteeseen siinä mielessä, että tavoittaisi, mitä kerrottu merkitsee kertojalle. Tarvitaan empaattista, ymmärtämään pyrkivää asennetta. Myötätuntoinen kuunteleminen on vaan pikemminkin neutraalia tutkimista, sen hahmottamista, mitä asiat ovat merkinneet kertojalle. Se ei sisällä arvostelua, mutta se ei kuitenkaan edellytä sitä, että olisi kaikissa asioissa samaa mieltä toisen kanssa. Kysymys on siitä, että hyväksyy sen, että toisen kertomat asiat kuuluvat tai ovat kuuluneet hänen elämäänsä. (Ks. Välikoski, 2016.) Kohtaamistaiteen parissa esitetty japanilainen mitate-käsite tarkoittaa toisen kokonaisvaltaista arvostavaa kohtaamista (Pusa, 2014, s. 6). Tällaista kohtaamista tarvitaan, kun työskennellään yhdessä taide- ja medialähtöisissä työpajoissa.

Esimerkiksi juuri syrjäytymisvaarassa olevilla nuorilla voi olla kokemuksia siitä, että keskustelukumppani ei hahmota esillä olevan asian merkitystä kertojalle, ei kykene tai pyri merkityksen tavoittamiseen. Tällöin yhteyttä ei muodostu, ihminen ei tule nähdyksi eikä kuulluksi vaikka yrittäisikin.

\section{Yhdessä tekeminen luo yhteistä tilaa}

Taide- ja medialähtöisissä menetelmissä käytetään arkisesta kommunikaatiosta poikkeavia ilmaisukeinoja, ja yhtenä tavoitteena on usein vuorovaikutuksen tukeminen. Ohjaajien tehtävänä on strukturoida toiminta niin, että se on mahdollista osallistujille - usein sellaisille, joilla ei ole lainkaan aiempaa kokemusta käytetystä ilmaisuvälineestä. Ohjaaminen ei ole varsinaista koulutusta tai opetusta, vaikka siinä voikin oppia monia asioita. Ohjaajakeskeistä vuorovaikutusta on syytä työpajoissa tietoisesti välttää. (Ks. Anttila ym., 2017.) Silti ohjaussuhde on perustaltaan epäsymmetrinen (ks. Janks \& Ivanič, 1992, ss. 306-307); ohjaajalla on enemmän valtaa ja vastuuta kuin ohjattavalla. Tästä syystä ohjaussuhde on omiaan tarjoamaan ohjaajille enemmän tilaa tulla esiin ja kuulluksi kuin ohjattaville. Jotta osallistujat rohkaistuisivat ja motivoituisivat toimimaan ryhmässä aktiivisesti, valtasuhteen epäsymmetrian osoittamista kannattaa pikemminkin purkaa kuin tuoda esiin. Se tarkoittaa sitä, että tietoisesti luodaan tasa-arvoisia osallistumisen ja kommunikoinnin mahdollisuuksia ja muotoja. Se, että ohjaajat tekevät samoja asioita kuin osallistujat, on yksi tällainen käytänne.

Näkymättömät - Nuorten digitarinat -hankkeen ja muissakin vastaavissa työpajoissa on havaittu, että ohjaajalle muodostaa kuitenkin oman haasteensa se, että ohjaamisen ohessa hän itsekin tekee yhtenä ryhmän jäsenenä ainakin jossakin määrin samoja asioita kuin muutkin osallistujat. Aivan kaikkea ohjaaja ei voi eikä ole mielekästäkään tehdä samanaikaisesti työpajaosallistujien kanssa, mutta on paikallaan pysähtyä miettimään, mitä voisi ja miten. Silloin kun ohjaa- 
jia on enemmän kuin yksi, tilanne on ratkaistavissa paremmin kuin silloin, jos ohjaajia on vain yksi.

Näkymättömät-työpajoissa kävi selväksi myös se, että dialogisen vuorovaikutussuhteen kannalta on tärkeää, että ohjaavat sisäistävät vuorovaikuttavansa ryhmässä kaiken sen ajan, joka työpajassa toimitaan yhdessä. Ohjaaja ei voi vetäytyä tilanteesta oman puheenvuoronsa jälkeen, vaan hän on koko ajan läsnä ainakin aktiivisena kuuntelijana. Huomion hajauttaminen multitaskaamiseen ei tule työpajaohjauksessa kysymykseen, sillä ohjaajan vetäytyminen omiin oloihinsa houkuttaa muitakin osallistujia tekemään samoin.

\section{Ohjaajan vastuu vuorovaikutuksesta}

Seuraavaksi tarkastellaan vuorovaikutukseen ja valtaan liittyviä havaintoja Näkymättömät - Nuorten digitarinat -työpajoista - otettavaksi huomioon esimerkiksi vastaavia työpajoja järjestettäessä. Havaintoja pohditaan vuorovaikutusta käsittelevän kirjallisuuden kanssa dialogia käyden.

Vastuu vuorovaikutuksen syntymisestä ja jatkumisesta ryhmässä jakautuu niin osallistujille kuin ohjaajillekin, mutta ohjaajilla on kuitenkin valtaasemansa vuoksi osallistujia suurempi vastuu. Siksi ohjaajan on tarpeen pohtia ja tiedostaa sitä, miten hän omilla verbaalin ja nonverbaalin viestinnän tavoillaan sekä toiminnallaan vaikuttaa ratkaisevasti siihen, millaisia rooleja hän omalla tulee ehdottaneeksi osallistujille ja miten osallistujien on mahdollista toimia tilanteessa. (Ks. Anttila ym., 2017.)

Osallistujien toimijuutta ja vuorovaikutussuhdetta on mahdollista lähestyä esimerkiksi psykiatri Eric Bernen kehittämän transaktioanalyysin käsitteiden avulla. Myös statusviestinnän ideat avaavat sitä, miten ja millaiseksi kommunikaatio muodostuu viestijöiden välillä.

Sosiaalipsykologi Juha Mikkonen luo katsauksen transaktioanalyysiin Psykologia-lehdessä (5/2006). Transaktioanalyysissä huomio kohdistetaan siihen, millaisena, millaisesta minätilasta, viestii suhteessa toiseen: ikään kuin vanhempana, aikuisena vai lapsena. Transaktioanalyysissä tarkastellaan itsen ja toisen välistä suhdetta myös elämänasenteen ja hyväksynnän näkökulmasta: näkeekö itsensä ja toisen ihmisen samanarvoisina, hyväksyttävinä tai mahdollisesti hyväksymättä, vai näkeekö itsensä ja toisen eriarvioisina, toisen hyväksyttävänä ja toisen hyväksymättä. Transaktioanalyysiin sisältyy myös lapsuudessa muodostuvan elämänkäsikirjoituksen käsite. Sen mukaan lapsi muodostaa vanhempien ja muiden läheisten ihmisten viestien perusteella käsikirjoituksen elämälleen ja pyrkii myöhemmin toteuttamaan sitä. Tällaisen käsikirjoituksen mahdollisesti rajoittavista tai estävistä piirteistä 
voi kuitenkin tulla tietoiseksi ja toimia tietoisesti toisin. Transaktioanalyysin kehittäjä Eric Berne pitää keskeisinä kolmea kykyä: tietoisuutta (läsnäoloa tässä ja nyt), välittömyyttä (valita vapaasti aikuisen, vanhemman tai lapsen tila kussakin tilanteessa) ja läheisyyttä. (Mikkonen, 2006, ss. 328-342; Suomen Transaktioanalyysiyhdistys Fin TA ry, 2018; TA Instituutti, 2018.)

Näyttelijä Simo Routarinne tarkastelee statusviestintää improvisaatio- ja vuorovaikutuskouluttaja Keith Johnstonen (ks. esim. Johnstone, ei pvm.) periaatteiden pohjalta teoksessa Valta ja vuorovaikutus (2008). Statusviestintää verrataan keinulautaan. Kommunikoitaessa statukset liikahtelevat: kun toinen nostaa omaa statustaan suhteessa toiseen, toinen vastaavasti laskee - ellei tilanne kärjisty statuskamppailuksi. Valtaa voidaan myös tietoisesti antaa toiselle. (Routarinne, 2008, ss. 10-12, 17-62, 140-146.) Statusviestinnän tiedostaminen on tarpeen näyttelijäntyön lisäksi esimerkiksi juuri ohjaustilanteissa.

Näkymättömät - nuorten digitarinat -työpajoissa näkyi se, että niin edellä mainittu transaktioteoriaan sisältyvä käsitys itsestä ja vuorovaikutuskumppanista kuin statusviestinnän teoriaan sisältyvä itsen ja toisen asema kommunikaatiotilanteessa ovat sekä koettuja että viestinnässä heijastuvia ja muotoutuvia asioita. Ne tuotetaan viestintätilanteessa verbaalisin ja nonverbaalisin keinoin, siis kommunikoimalla sanoilla, äänellä, eleillä, ilmeillä ja tilankäytöllä. Vuorovaikutustilanne on vastavuoroinen; tietynlainen kommunikoinnin tapa kutsuu tai mahdollistaa tietynlaisia kommunikoinnin tapoja. (Ks. Mikkonen, 2006, ss. 328-342; Routarinne, 2008, ss. 10-12, 17-62, 140-146.)

Työpajassa ohjaajan on tarpeen havainnoida ja säädellä sitä, millaista identiteettiä vuorovaikutuskumppanille muodostaa kielenkäytössään: esimerkiksi toimijan, kohteen vaiko peräti uhrin asemaa. Samoin on syytä tiedostaa se, millaista vuorovaikutussuhdetta kielenkäytössään rakentaa: korostuuko siinä epäsymmetrinen valta-asema vai tuodaanko esiin myös muita vaihtoehtoja. Tärkeää on se, että ohjaaja tukee osallistujien toimijuutta antamalla tilaa ja valtaa osallistujille esimerkiksi juuri säätelemällä omaa statusviestintäänsä - sen lisäksi, että hän puhuen motivoi, rohkaisee ja mahdollistaa. Olennaista on myös se, että ohjaaja ymmärtää viestivänsä sekä tietoisesti että tiedostamatta - jolloin keskittyminen vuorovaikutustilanteeseen on välttämätöntä. (Ks. Kide, 2014, ss. 54-65, 102, 105.)

Osallistujien toimijuutta voidaan rakentaa osaltaan verbaalissa viestinnässä. Kysymys on esimerkiksi siitä, millaista sanastoa käytämme, mutta ei yksin siitä. Sen lisäksi on otettava huomioon hyvin hienovaraisia kielellisen ilmaisun resursseja ja vuorovaikutustilanne kokonaisuutena. Olennaista on säädellä sitä, millaista maailmaa kielenkäytöllä heijastamme ja muodostamme: Millaista vuorovaikutussuhdetta rakennamme osallistujien välille? Millaista asemaa muodostamme vuorovaikutuskumppanille ja itsellemme? Millaisena tuomme esiin esi- 
merkiksi toiminnan? Kielenkäytön sätelyssä on otettava huomioon, millaiset kommunikoinnin keinot ovat tietyssä tilanteessa mahdollisia, millaiset taas eivät. Kielenkäytön ja muun vuorovaikutuksen säätely on käytännön kriittistä diskurssianalyysia. (Ks. Eggins, 1994, ss. 10-11, 330; Fairclough, 1997, s. 76, 2003 b, 8-10; 2010, ss. 56-59, 95-96; Juhila, 1999, s. 162; Pietikäinen \& Mäntynen, 2009, ss. 58-59; Scollon \& Scollon, 2004, s. 8.)

\section{Osallisuutta tukeva diskurssi}

Millaista sitten on osallisuutta tukeva diskurssi, puhetapa? Siihen tarvitaan osallisuutta mahdollistavia ratkaisuja niin sosiaalisten käytäntöjen kuin kirjoitettujen ja puhuttujen tekstien tasolla (ks. Fairclough, 2010, s. 59). Tarvitaan eri alojen ammattilaisten yhteistyötä, vuorovaikuttamisen mahdollistamista erilaisissa kohtaamistilanteissa ja toimijuutta muodostavaa kommunikaatiota.

Vuorovaikutuskumppanille on tarpeen tarjota nimenomaan toimijan, valintoja tekevän henkilön roolia kohteen roolin sijaan, kun tavoitteena on osallisuuden tukeminen. Tämä tehdään osaltaan tietoisilla sanavalinnoilla. Muutama esimerkki siitä, miten sanoilla voi ilmaista toimijuutta tai kohteena olemista: Kasvatti-sana tuo kasvajan esiin kasvatuksen kohteena, kun taas kasvaja-sana toimijana. Sana opiskelija sisältää oppijan oman toimijuuden vahvemmin kuin sana oppilas. Sana osallistuja ilmaisee osallisuutta ja toimijuutta, mutta sillekin voi olla vaihtoehtoja. Esimerkiksi yhteisötaiteellisissa työpajoissa saatetaan puhua osallistujien sijaan taiteilijoista. Tällöin tekijyys osoitetaan kaikille osapuolille.

Sanallisen vuorovaikutuksen lisäksi osallisuus on tarpeen ottaa huomioon muutenkin diskursiivisissa käytänteissä. Olennaisen tärkeää on virittää aito mielenkiinto. Ruoka vetää puoleensa lähes varmasti. Siitä on hyvä edetä muihin asioihin ja toimintoihin.

Työpajoissa yksi kriittinen vaihe on heti alussa, kun määritellään toimintatavat. Kun tavoitteena on osallisuuden tukeminen, toimintatavat sovitaan mieluiten yhdessä kaikkien osallistujien kesken. Toimintatapoja määriteltäessä on tarpeen kiinnittää ilmaisuihin: saatetaan puhua esimerkiksi säännöistä tai sopimuksista. Sopimusten tekemiseen osallistuvat muutkin kuin ohjaajat, mutta säännöt ovat usein luonteeltaan sellaisia, että joku määrittää ne ja velvoittaa muut noudattamaan niitä. Niin sääntöjä kuin sopimuksiakin voidaan tehdä myös yhdessä, joten kysymys ei ole yksin sanavalinnasta, mutta on syytä tiedostaa, että kielenkäyttö sekä heijastaa että ohjaa toimintaamme, näkemystämme maailmasta, arvojamme ja asenteitamme (ks. Hacking, 2004, ss. 24, 35, 40, 67, 73-74, 100, 2009, ss. 40-43, 48-51, 67-68, 100; Pietikäinen \& Mäntynen, 2009, ss. 11-15). 
Toinen kriittinen vaihe on palautteen antaminen. Siinä syntyy helposti asetelma, jossa palautteen antaja asettuu keskustelun kohteena olevan tuotoksen ja tekijän yläpuolelle ja arvottaa kaksinapaisella akselilla: hyvä-huono. Tällaista otetta hedelmällisempi kommunikointitapa on merkitysten hahmottaminen yhdessä. Epäsymmetristä valta-asemaa on mahdollista purkaa esimerkiksi siten, että palautteen antaja tuo esiin, millaisia ajatuksia, tunnelmia ja tunteita tuotoksen äärellä herää. (Ks. Rankanen, 2007, s. 95.) Tällöin palautteenantajan, tuotoksen ja tekijän välille syntyy dialogi, ja asetelma ei ole ainakaan niin epäsymmetrinen kuin se on lähtökohdaltaan arvioivassa ja arvottavassa kommentoinnissa.

Huomiota on tarpeen kiinnittää myös siihen, missä määrin ohjaaja puhuu ja kirjoittaa omalle ammattialalleen ominaisilla puhetavoilla. Eri ammattialojen professionaalit diskurssit ovat tuttuja ammattilaisille mutta eivät välttämättä muille. Ammatillisille diskursseille ominaista on se, että ne mahdollistavat tehokkaan viestinnän ammattilaisten kesken ja tukevat ammattilaisten keskinäistä ryhmähenkeä, mutta suhteessa muihin kuin oman alan ammattilaisiin ne voivat toimia pikemminkin erottavina, ulos sulkevina tai objektivoivina puhunnan tapoina. (Dijk, 2008, ss. 51, 67-69.)

Tarvitaan siis sellaista puhetapaa, jossa vuorovaikutuskumppanit tulevat esiin toimijoina ja jonka he voivat tunnistaa itselleen ominaiseksi tai ainakin mahdolliseksi. Taide- ja medialähtöisiä menetelmiä sovellettaessa asiat, joista kommunikoidaan, ovat tyypillisesti yleisinhimillisiä, sellaisia, että ne pikemminkin yhdistävät kuin erottavat ihmisiä. Jokaisen havainnot, kokemukset ja ajatukset ovat kuitenkin yksilöllisiä.

Turun Näkymättömät-digitarinatyöpajoissa nuoret tekivät koskettavia digitarinoita ja olivat tyytyväisiä ja yllättyneitäkin tuotoksistaan. Palautteissa he kertoivat kokeneensa itse prosessin merkitykselliseksi, jopa merkityksellisimmäksi. Ilmiö on tuttu esimerkiksi yhteisötaiteesta, jonka tavoitteisiin vuorovaikutuksen tukeminen kuuluu (ks. esim. Roponen-Lunnas, 2013). Prosessiin sisältyy juuri vuorovaikutus ja siinä tapahtuvat kohtaamiset, näyttäytymiset ja kuulluksi tulemiset - digitarinoiden tekemisen, esittämisen ja katselun muodossa. Se, että nimenomaan itse prosessi ja siihen sisältyvä kommunikaatio on koettu työpajoissa merkittävimmäksi, osoittaa osaltaan juuri sen, että näyttäytyminen ja nähdyksi tuleminen ovat tärkeitä asioita, joihin meillä kaikilla on tarve ja toivottavasti myös tilaisuus.

\section{Kehittämisen tarpeet}

Laki yleisistä kirjastoista (1492/2016) näkee kirjastot toimijoina, joilla on hyvät mahdollisuudet tavoittaa yhteisöjä ja yksilöitä, ja ehkä juuri siksi kirjastoille 
tarjotaan aktiivista roolia kansalaisyhteiskunnassa. Lain tavoitteena on edistää väestön yhdenvertaisuutta, monipuolista lukutaitoa, elinikäistä oppimista, aktiivista kansalaisuutta ja demokratiaa. Tämän lisäksi laki korostaa kirjastojen mahdollisuuksiin vaikuttaa yhteisöllisyyteen ja moniarvoisuuteen yhteiskunnassa sekä kulttuurien moninaisuuteen. Lain valmisteluasiakirjat (HE 238/2016) noustavat esiin yleisen kirjaston matalan kynnyksen: kirjasto on saavutettavissa ja sen tilat avoimia. Yleinen kirjasto on nähty solmuna, joka sitoo ihmisiä ja toimijoita yhteen. Tämä voi tarkoittaa kiinnekohtaa mutta myös aktiivista yhteistyökumppanuutta, julkisen, yksityisen kuin kolmannen sektorin välisten verkostojen kutojaa.

Näkymättömät-hanke (2015-2018) on kehittänyt Topit-mallin ja käsikirjan tukemaan yleisiä kirjastoja. Tavoitteena on, että kirjastot rohkaistuisivat tavoittamaan niitä nuoria aikuisia, jotka ovat riskissä ajautua yhteiskunnan marginaaliin. Tavoittaminen on ensimmäinen askel, mutta yksin se ei riitä, vaan nuoret olisi saatava mukaan yhteisön toimintaan. Hankkeen alussa tehty kartoitus osoitti, että yleisten kirjastojen tiedot riskiryhmän nuorista aikuisista vaihtelevat, asia ja haaste on tunnistettu, mutta toimenpiteet ovat toistaiseksi olleet melko vaatimattomia. Osittain tilannetta hankaloittaa se, että 15-29-vuotiaiden ikäryhmä lävistää kirjastojen palvelualueet. Toinen kriittinen kohta on se, että kirjaston palvelujen ydintä ovat kirjallisuus ja lukeminen, mutta nuorten lukutaito on heikkenemässä ja kiinnostus kirjallisuutta kohtaan on vähentynyt. Topitmallia kehittäessä Näkymättömät-hanke on kuullut sensitiivisiä ja rankkoja tarinoita nuorilta ihmisiltä, jotka ovat syystä tai toisesta liukumassa ulkokehälle. He eivät ole lukijoita, eikä kirjoittaminen ole heidän vahvuutensa. Tämä ei tarkoita, etteikö heillä olisi sanottavaa, mutta osaammeko luoda tilanteen kuunnella heitä? Yhteisöllisyys on hieno arvo, johon liittyy toisen kunnioitus, tukeminen ja luottamus. Ovatko nämä nuoret aikuiset yhteisöllisen osaamisen todellinen mittari?

\section{Lähteet}

Allianssi. (2016). Nuorista Suomessa 2016: tietoa nuorista, heidän elinoloistaan sekä nuorisotyöstä. Helsinki: Suomen Nuorisoyhteistyö. http://www.alli.fi/binary/file/-/id/665/fid/5195/ Anttila, E., Pohjola, H., \& Löytönen, T. (2017). Ihmis- ja oppimiskäsitykset taideopetuksessa (Vsk. 58). Teatterikorkeakoulun julkaisusarja 58. http://hdl. handle.net/10138/185061

Burns, E. A., Howard, J. K., \& Kimmel, S. C. (2016). Development of communities of practice in school library education. Journal of Education for Library and Information Science, 57(2), 101-111. https://eric.ed.gov/?id=EJ1096674

Dijk, T. A. van. (2008). Discourse and power. New York, N.Y: Palgrave Macmillan.

Eggins, S. (1994). An introduction to systemic functional linguistics (2. p.). London: Continuum. 
Eurostat. (2016). Education, employment, both or neither? What are young people doing in the EU? Eurostat News Release 155/2016 (3-11082016-AP). http://ec.europa.eu/eurostat/web/ products-press-releases/-/3-11082016-AP

Fairclough, N. (1997). Miten media puhuu. (V. Blom \& K. Hazard, käänt.). Tampere: Vastapaino.

Fairclough, N. (2010). Critical discourse analysis: the critical study of language (2. p.). Pearson education.

FINLEX. (2016). Hallituksen esitys eduskunnalle laeiksi yleisistä kirjastoista ja opetus- ja kulttuuritoimen rahoituksesta annetun lain 2 \$:n muuttamisesta. https://www.finlex.fi/fi/ esitykset/he/2016/20160238

FINLEX 1492/2016. (ei pvm.). Laki yleisistä kirjastoista 1492/2016. https://www.finlex.fi/fi/ laki/alkup/2016/20161492

Gutsche, B., \& Hough, B. (2014). Competency index for the library field. OCLC WebJunction. https://www.webjunction.org/documents/webjunction/Competency_Index_for_the_Library_ Field.html

Hacking, I. (2004). Historical ontology. Cambridge, Mass.: Harvard University Press.

Hacking, I. (2009). Mitä sosiaalinen konstruktionismi on? (I. Koskinen, käänt.). Tampere: Vastapaino.

Harju, A. (2003). Yhteisellä asialla: kansalaistoiminta ja sen haasteet. [Helsinki]: Kansanvalistusseura.

Harju, A. (2018). Kansalaisyhteiskunnan määritelmä ja sisältö - Kansalaisyhteiskunta.fi. Kansalaisyhteiskunta.fi. https://www.kansalaisyhteiskunta.fi/kansalaisyhteiskunta/ kansalaisyhteiskunnan_maaritelma_ja_sisalto

Heikkinen, V. (1999). Ideologinen merkitys: kriittisen tekstintutkimuksen teoriassa ja käytännössä. Helsinki: Suomalaisen Kirjallisuuden Seura.

Janks, H., \& Ivanič, R. (1992). Critical language awareness and emancipatory discourse. Teoksessa N. Fairclough (toim.), Critical language awareness (ss. 305-331). London; New York: Longman.

Järvelin, K. (1989). Tiedontarpeet ja hankinta tutkimuskohteena. Kirjastotiede ja informatiikka, 8(2), 55-59. https://journal.fi/inf/article/view/1372

Johnstone, K. (ei pvm.). Status. https://www. youtube.com/watch?v=MbwMyyQ23NY

Joy, E. E., \& Vijayakumar, K. P. (2016). The relevance of communities of practice (Cop) in university libraries: a knowledge management perspective. SRELS Journal of Information Management, 53(5), 359-365. https://doi.org/10.17821/srels/2016/v53i5/91105

Juhila, K. (1999). Tutkijan positiot. Teoksessa A. Jokinen, K. Juhila, \& E. Suoninen (toim.), Diskurssianalyysi liikkeessä (ss. 201-232). Tampere: Vastapaino.

Junttila, N. (2015). Kavereita nolla: lasten ja nuorten yksinäisyys. Helsinki: Tammi.

Karvonen, P. (1995). Oppikirjateksti toimintana. Suomalaisen Kirjallisuuden Seuran toimituksia 632, Helsinki: Suomalaisen Kirjallisuuden Seura.

Kide, T. (2014). Kelluntamusiikki: improvisoinnin opetusmenetelmä. Studia musica 55, Helsinki: Sibelius-Akatemia.

Kim, J.-A. (2015). Integrating communities of practice into library services. Collaborative Librarianship, 7(2). https://digitalcommons.du.edu/collaborativelibrarianship/vol7/iss2/2

Kurki, L. (2000). Sosiokulttuurinen innostaminen: muutoksen pedagogiikka. Tampere: Vastapaino.

Lave, J., \& Wenger, E. (1991). Situated learning : legitimate peripheral participation. Learning in doing: social, cognitive, and computational perspectives, Cambridge: Cambridge University Press.

Lloyd, A. (2005). No man (or woman) is an island: information literacy, affordances and communities of practice. Australian Library Journal, 54(3), 230-237. https://doi.org/10.1080/ 00049670.2005 .10721760 
Lukukeskus. (2017). 10 faktaa lukemisesta. http://www. lukukeskus.fi/10-faktaa-lukemisesta2017/

Miettinen, Virpi. (2016). Nuoret haluavat rohkeamman kirjaston. Oodi Helsinki. http://www. oodihelsinki.fi/nuoret-haluavat-rohkeamman-kirjaston/

Mikkonen, J. (2006). Transaktioanalyysi persoonallisuus- ja vuorovaikutusteoriana, 328-344. http://urn.fi/URN:NBN:fi:ELE-1348018

Näkymättömät - Nuorten digitarinat 2018. (ei pvm.). https://www.youtube.com/channel/ UCOXR9J5ZqL2jKu7JSO0LJ0A

Oma Linja. (2016). Oma linja -infopaketti 1: eriarvoistuva peruskoulu. Omalinja. http://omalinja.fi/ajankohtaista/oma-linja-infopaketti-1-eriarvoistuva-peruskoulu/

Parkkinen, T., \& Linnossuo, O. (2013). Harjoitteita nuorten taidelähtöisen ryhmäohjauksen tueksi. Teoksessa E. Sinisalo-Juha, J. Krappe, \& T. Parkkinen (toim.), Tavarat taskuissa: nuorten ryhmäohjauksen taidelähtöisiä menetelmiä. MIMO-projekti 2010-2013. Turun ammattikorkeakoulun oppimateriaaleja, Helsinki: Turun ammattikorkeakoulu \& Humanistinen ammattikorkeakoulu. http://urn.fi/URN:ISBN: 978-952-456-156-3

Pietikäinen, S., \& Mäntynen, A. (2009). Kurssi kohti diskurssia. Vastapaino.

Pusa, T. (2014). Kohtaamistaide: käsikirja ohjaajalle. (T. Pusa, toim.). Laurea julkaisut, Vantaa: Laurea-ammattikorkeakoulu. http://urn.fi/URN: ISBN: 978-951-799-332-6

Rankanen, M. (2007). Työskentelyn eteneminen taideterapiassa. Teoksessa M. Rankanen, H. Hentinen, \& M.-H. Mantere (toim.), Taideterapian perusteet (ss. 91-97). Helsinki: Duodecim.

Roponen-Lunnas, P. (2013). Kohtaamisen taide - yhteisötaiteen ideaaleja ja käytäntöjä. Tahiti, (4/2013). http://tahiti.fi/04-2013/dossier/kohtaamisen-taide-/\%e2/\%80/\%93yhteisotaiteen-ideaaleja-ja-kaytantoja/

Routarinne, S. (2008). Valta ja vuorovaikutus: statusilmaisun perusteet. Helsinki: Tammi.

Salonen, S. (2017). Syrjäytyminen väistää määritelmiä. Sosiaalivakuutus. https: //sosiaalivakuutus.fi/syrjaytyminen-vaistaa-maaritelmia/

Scollon, R., \& Scollon, S. (2004). Nexus analysis: discourse and the emerging internet. London: Routledge.

Sinisalo-Juha, E. (2013). Työskentely nuorten ryhmien kanssa. Teoksessa E. Sinisalo-Juha, J. Krappe, \& T. Parkkinen (toim.), Tavarat taskuissa: nuorten ryhmäohjauksen taidelähtöisiä menetelmiä. MIMO-projekti 2010-2013. Turun ammattikorkeakoulun oppimateriaaleja 83, Helsinki: Turun ammattikorkeakoulu \& Humanistinen ammattikorkeakoulu. http://urn.fi/URN: ISBN : 978-952-456-156- 3

Suomen Transaktioanalyysiyhdistys Fin TA ry. (2018). Mitä TA on? http://finta.net/mita-taon/

TA Instituutti. (2018). Mitä transaktioanalyysi eli TA on? http://www.transaktioanalyysi.fi/ mika-TA/transaktioanalyysi

THL. (2017). Osallisuus. https://www.thl.fi/fi/web/hyvinvointi-ja-terveyserot/ eriarvoisuus/hyvinvointi/osallisuus

Turun ammattikorkeakoulu. (2018). Innovaatiopedagogiikka. https://www.turkuamk.fi/fi/ turun-amk/tunne-meidat/innovaatiopedagogiikka/

UN. (2016). Leaving no one behind: the imperative of inclusive development. Report on the World Social Situation 2016. United Nations. http://www.refworld.org/docid/5840368e4.html

Välikoski, T.-R. (2016). Kuuntelemisen taito. Viestijät 15.6.2015. Viestinnän ammattilaiset ry. https://viestijat.fi/kuuntelemisen-taito/

Wenger, E. (1998). Communities of practice : learning, meaning, and identity. Learning in doing: social, cognitive, and computational perspectives, Cambridge: Cambridge University Press. 